\title{
The Effectiveness of Implementation of the MGMP Revitalization Program as a Media Increasing English Teacher Competency in Pidie District
}

\author{
Ramlan, ${ }^{2}$ Farizawati, ${ }^{3}$ Saddam Hasrul \\ ${ }^{1,2}$ English Lecturer at Jabal Ghafur University, Aceh, Indonesia \\ ${ }^{3}$ English Lecturer at University of Gunung Leuser, Indonesia \\ ramlanmhum@gmail.com
}

\begin{abstract}
This research was conducted to determine the effectiveness of the revitalization program for Teacher's Deliberation of Course of Study (MGMP) as a medium to improve English teacher competency. The research method applied in this study is evaluative research based on (Arikunto 2007: 222) evaluative research can be interpreted as a process carried out in order to determine policy by first considering the positive values and benefits of a program, as well as considering the processes and techniques that have been used to do a research. The results showed that each participant's positive reaction to the implementation of the program could significantly influence the increase in knowledge and skills for each participant / program participant in relation to the philosophical and theoretical basis of learning English in secondary schools. However, increasing knowledge and skills did not always have an impact significant at the practical level, namely the quality of the learning process carried out by teachers, participants in the MGMP revitalization program, in the classroom. Teachers still tend to use conventional patterns in the process of learning English.
\end{abstract}

Keywords

scout activity; state

defends attitude

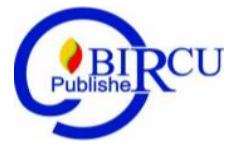

\section{Introduction}

It is expected that the quality of the Indonesian people can face increasingly fierce competition with other countries in the world, of course the quality is produced through the provision of quality education. Along with global challenges, education is very important because education is a determinant of the quality of Sumber Daya Manusia Human Resources (SDM). The quality of SDM is positively correlated with the quality of education, and the quality of education is often indicated by good conditions, compliance with requirements and all components that must be contained in education. These components are input, process, output, education staff, infrastructure and costs. The quality of education will be achieved if contributions, processes, results, teachers, facilities and infrastructure, as well as costs are available and implemented properly. But of the various components that play a more important role are qualified or qualified teachers (Sri Damayanti, 2008). To improve the quality and competence of teachers, teachers must have professional standards in mastering the material and learning strategies and can encourage students to learn seriously.

In accordance with the Law of the Republic of Indonesia Number 14 of 2005 concerning Teachers and Lecturers Article 2 paragraph (1) confirms that teachers have the position of professionals at the level of basic education, secondary education, and early childhood education in the formal education pathways adopted in accordance with regulations legislation. Article 4 also explains that the position of the teacher as a 
professional as referred to in Article 2 paragraph (1) serves to improve the dignity and role of the teacher as an agent of learning functions to improve the quality of national education.

On the other hand, teacher professionalism in Indonesia is still far from what was expected: 3.9 million teachers are currently available, $25 \%$ of them do not meet the qualification criteria and 52\% do not have professional certificates. However, a teacher in carrying out his duties must have competency standards that include pedagogical, personal, social and professional skills (Yunus, 2017). In addition, based on the results of the skills test, the average teacher skills score was only $42.25 \%$, which was significantly lower than the expected minimum skill score of $75 \%$. In addition, according to the Human Development Index (HDI), teachers who have teaching qualification standards range from $60 \%$ for elementary schools, $40 \%$ for junior high schools, $34 \%$ for high schools. and 17, $2 \%$ of teachers teach not according to their field of

study or educational background (Arni Hayati, 2009). To streamline the teacher training program, in 2015 the government through the Ministry of Education and Culture has conducted a Teacher Competency Test (UKG) and set a value of 55.50 as the UKG graduation standard as a mapping of teacher competency values throughout Indonesia. English language teachers in Pidie Regency have also taken UKG to see the ability of teachers in the district. The UKG results show that $86 \%$ of teachers in the district have not yet passed the UKG(Dinas pendidikan Pidie, 2015). Culture is a manifestation of ethnic theology and cosmology (Zulkifli and Ridwan, 2019).

The data shows that the average ability of English teachers in Pidie district is still below the minimum standard value. As one of the developing cities in the province of Aceh, it must have English teachers with high professional and pedagogical competencies, in addition, the presence of MGMP in English in Pidie district has received guidance from related institutions such as the Education Office, however, the English MGMP unable to take advantage of this attention and support. It is assumed that creativity, vitality of members and management cannot determine the existence and development of the English language MGMP. Specifically, it is hoped that the MGMP can improve the professional competence and pedagogy of English teachers in Pidie District.

Subject Teacher Consultation (MGMP) is a professional forum for subject teachers in district, city, sub-district or school areas. The principle works is the activity, by, and for teachers from various schools. On this basis, MGMP is a non-structural organization that is independent, family-based, and has no hierarchical relationship with other institutions. This is in line with Soetjipto and Raflis (2009: 36) which states that MGMP is a type of school teacher organization that is recognized by the government to date. MPMP was established on the recommendation of Ministry of Education and Culture officials. "Meanwhile (Ondi Saondi and Aris Suherman,

2010: 80) said this communication forum for the profession was needed to contribute to increasing the professionalism of its members, not only to increase the capacity of teachers in terms of developing learning tools, but also to increase the teacher's capacity, knowledge, knowledge and understanding of the material being taught and its development.

Looking at the above view, we can say that MPGP is basically an increase in work skills, better known as the Education and Training Program. The government has also set the objectives of the English Language MGMP activities as follows. (1) Expanding teacher's insights and knowledge in various ways, especially mastery of teaching materials, compiling syllabus, compiling learning materials, learning strategies, learning methods, maximizing the use of 
learning facilities / infrastructure, utilizing learning resources, utilizing teacher abilities, developing teacher or professional abilities etc. (2) Providing opportunities for members of work groups or work meetings to share experiences and provide mutual assistance and feedback. (3) Enhancing knowledge and skills, and adopting a more professional approach to learning for work group participants or work meetings (4) Empowering and assisting work group members in carrying out learning tasks at school. (5) Change the work culture of work group members or work meetings (increase knowledge, competencies, and performance) and develop teacher professionalism through professionalism development activities at the MGMP level. (6) the quality of the education and learning process which is reflected in the improvement of student learning outcomes. (7) improve teacher competency through activities at the MGMP level.

According to (Suyanto, 2013) so that the objectives of the MGMP can be achieved, various steps need to be taken in determining the form and process of the MGMP, as follows. (a) Determination of educational and training needs, or a comprehensive comprehensive assessment (b) Establishing general and specific goals (c) Choosing methods (d) Choosing media (e) Implementing programs (f) Evaluating programs.

\section{Review of Literature}

\subsection{Basic Framework and Structure of the MGMP Program}

Based on the basic framework of the program, MGMP activities refer to the Regulation of the Minister of National Education of the Republic of Indonesia No. 16 of 2007 concerning qualifications and standards of teacher competencies, including educational competencies, personality competencies, professional competencies and social competencies. For each competency can be described as follows:

Pendagogik Competence is a set of abilities and skills related to interaction of teaching and learning in class, how teachers understand students, design and implementation of learning, class management, evaluation processes in learning and development of students so that they can actualize all their abilities to the maximum. The indicators of this pedagogical competence are understanding students by utilizing the principles of cognitive development, understanding the foundation of education, applying learning and learning theories, determining learning strategies and developing learning designs that are appropriate to the conditions of students. (b) Personality competence is a set of abilities and personal characteristics that reflect the reality of the attitudes and behavior of teachers as educators. This personality competence will give birth to a personality that is stable, stable, wise and authoritative, noble in character so that it becomes an

example for their students. The indicators include acting in accordance with legal norms and social norms, displaying independence in all his actions as an educator, all his actions have benefits for students, schools and the community. (c) Professional competence is a set of abilities and skills for mastery of mastery material in depth, intact and comprehensive. It means that the teacher needs to have a wide and in-depth mastery of learning material, including mastery of curriculum material, scientific substance, and methodology. The indicators are understanding the teaching materials in the school curriculum, understanding the relationship between concepts related subjects, understanding the steps of research related to the field of science. (d) Social competence is a set of knowledge and skills related to relationships or interactions with others. In this social competence teachers are required to be able to communicate and interact effectively with 
students, fellow educators, parents, guardians of students and surrounding communities. The indicators are able to communicate and socialize effectively. The teacher is an elite figure of the community who is considered to have moral authority that is large enough so that he must have the ability to relate and communicate with others.

Based on the explanation above, the four competencies are integrative and holistic, which means that these skills need to be integrated into every teacher's actions and activities as a whole and holistically. As a professional teacher must have all four competencies. However, during the

2013 program implementation, academic mastery and professional competence were absolute requirements to be fulfilled. Specifically, for an English teacher, the four competencies above must be manifested in a number of more concrete communicative competencies. According to (Celce-Murcia et al, 1995: 5-35). The communicative competence includes (1) discourse competence competence, namely competence to understand the text produced in a real communication event in a particular context; (2) actional competence in act language competence, namely competence in labeling a step of communication in spoken language; (3) linguistic competence linguistic competence, namely competence to master various components (grammar, phonology, pronunciation, vocabulary, etc.) and English characteristics; (4) sociocultural competence, socio-cultural competence, namely mastery of the procedures or ethics of communicating in English; and (5) strategic competence, strategic competence, i.e. competencies related to effective communication strategies (oral or written) in a particular context. Based on Celce-Murcia's explanation that these five competencies play an important role in supporting English teachers, especially in applying English as a colloquial language daily

communication tool as well as communication in the scientific world of scientific language, naturally according to the way native speakers of English communicate. In addition, the communicative competence has implications for how an English teacher must teach the language to each student.

Knowledge of correct grammar can help teachers monitor and improve themselves and students in the communication process. Strategic competence will encourage English teachers to create a learning process that is fun and interesting for students. On the other hand, sociolinguistic competence can help English teachers train students in communication by using grammar and choice of words based on social context.

\subsection{Competence of English Teachers}

Competence is defined as knowledge, skills and fundamental values that are reflected in the habits of thinking and acting. Other meanings of competencies are one's specifications, knowledge, skills and attitudes and their application in the workplace, according to the performance standards required in the field. Teacher Competency Teacher competence refers to the ability of a teacher to fulfill his responsibilities responsibly and appropriately. According to Hamzah B. Uno (2008: 28), there are several abilities that are demanded from teachers in order to foster interest in the learning process, namely: (1) Being able to describe learning materials into various forms of delivery; (2) Being able to formulate goals for high-level cognitive learning, such as analysis, synthesis, and evaluation. Through these objectives the learning activities of students will be more active and comprehensive; (3) Mastering various effective learning methods according to the types and learning styles possessed by individual students; (4) Having a positive attitude towards the task of his profession, so that he always strives to improve the ability to carry out his duties as a teacher; 
(5) Skillful in making simple teaching aids according to needs with the demands of the subjects they are developing and their use in the learning process; (6) Skillful in using various models and learning methods that can foster interest so that optimal learning outcomes; (7) Skillful in interacting with students by considering the objectives and subject matter, conditions of students, learning atmosphere, number of students, time available, and factors relating to the teacher himself; (8) Understanding the nature and character of students, especially their learning abilities and study habits, interest in learning, motivation to learn, and learning outcomes that have been achieved; (9) Skillful and use existing

learning resources as material or learning media for students in the learning process; (10) Skillful in managing classes or leading students in learning so learning becomes interesting and fun.

Therefore, each teacher's competency will show the true quality of the teacher. This competency will be manifested in the form of mastery of knowledge, skills and professional attitudes in the implementation of functions as a teacher, as well as the ability to carry out tasks that are the responsibility of the teacher, which is part of the teacher's professional competence. Based on the opinions of experts, the teacher's task can be concluded, namely (a) teaching, guiding and training students, (b) teacher professional development, (c) community service. To carry out the above tasks and responsibilities, a teacher is required to have certain skills and abilities.

The formulation of the problem regarding the effectiveness of the program in this evaluative study was formulated as follows: 1. How did each participant react to the English MGMP activity in Pidie District? 2. To what extent has every teacher mastered knowledge and skills regarding the theoretical and philosophical foundations of English subjects after participating in the English Language MGMP activities in Pidie District? 3. How is the motivation of each participant in the English MGMP activity to transfer knowledge and skills into the English learning process? 4. What is the impact of the English MGMP activities on the development of English teacher professionalism in Pidie District?

The focus of this research are to get an idea of the effectiveness of the MGMP to improve the competence of English teachers in Pidie Regency. 1. Analyze each participant's reaction to the English MGMP activities in Pidie District. 2. Describe knowledge and skills regarding the theoretical and philosophical foundations of English subjects after participating in the English Language MGMP activities in Pidie District. 3. Analyze the motivation of each participant in the English MGMP activities to transfer knowledge and skills into the English learning process. 4. Analyze the impact of MGMP English activities on the development of English teacher competencies in Pidie District.

\section{Research Method}

In an effort to support the Aceh government program with the government's objective in implementing Aceh Carong (Aceh Smart), one of the Aceh Governor's priority programs in the field of education is to improve quality and smart cities expressed in the work mission of Pidie District. This research was conducted in Aceh Pidie district, Aceh province, because Pidie district is one of the developing cities and cities that depend on the quality of human resources who have school graduates with good English communication skills. The research method used in this study is evaluative research. According to (Arikunto 2007: 222) evaluative research can be interpreted as a process undertaken to determine policy by first considering the positive values and benefits of a program, as well as considering the 
processes and techniques that have been used to conduct research. This means that the data collected is not just numbers, but data comes from field notes (observations), interviews (documentation analysis) and questionnaires.

The research conducted by using instrument was carried out in three ways, namely by distributing questionnaires (questionnaires), field notes (observations) and interviews (documentation analysis). This evaluative research process follows four Kir Kiratrick evaluations (1996: 21) which contain evaluations of reactions, learning, behavior and results. Evaluation of the reactions carried out to study the impressions or reactions of each participant asked participants to be asked and interested in the English MGMP program that was carried out. Evaluation on learning is done to learn which knowledge and skills are mastered by each participant while studying in the MGMP activities. While behavioral evaluations are conducted to learn whether each MGMP participant has changed their performance by applying the knowledge and skills learned during the discussion in the English MGMP activities. Finally, the focus on the results of the evaluation is to study the activities of the English MGMP on improving teacher competency which increases the ability to improve the quality of teaching materials and improve the quality of learning better.

\section{Discussion}

\subsection{Data Analysis}

Based on explained above, this evaluative study is intended to find out the effectiveness of SMPN2 English MGMP activities in order to improve the competence of English teachers so that the quality of mastery of teaching materials and learning practices in the classroom is getting better. In accordance with the characteristics of the activity, this evaluative study applies the Kirkpatrick four-stage evaluation model (Kirpatrick's Four-level Evaluation Model). Variables that are the focus of this study include the teacher's reaction to the implementation of MGMP activities, teacher's knowledge and skills after participating in MGMP activities, teacher's motivation to transfer knowledge and skills, and the impact of MGMP activities on increasing teacher cometensi. Explicitly, the relationship between variables in this study can be described as follows:

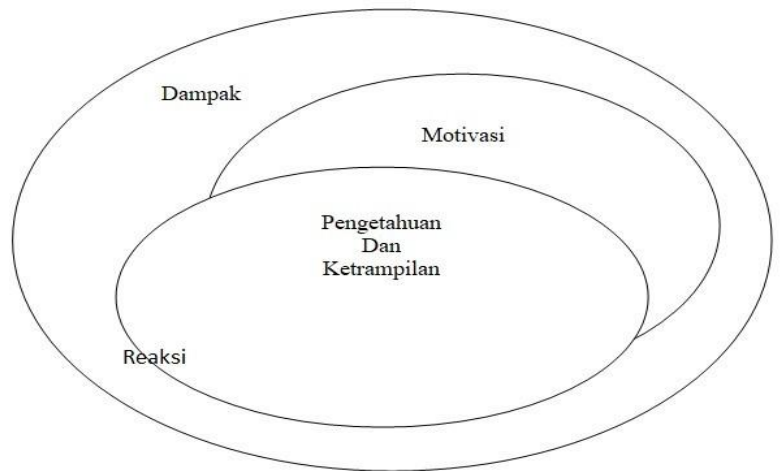

Figure 1. The relationship between variables

The data in this study were collected through three different techniques, namely questionnaires, observations, and interviews. The data obtained was then tested using regression analysis. To determine whether the three antecedent variables affect the impact of teacher competence or not, a regression analysis is carried out by following a four-step procedure. Four regression equations are used to test the relationship between variables in 
this study. In addition, the analysis of inter variable correlation was also observed to find out the magnitude of the correlation coefficient between the variables.

\subsection{Research Results}

The results of evaluative research on the implementation of the MGMP English language revitalization program show that the positive reaction of each participant to the implementation of the program has influenced the level of mastery of the knowledge and skills possessed by each participant. However, the acquisition of knowledge and skills does not always have a significant impact on the quality of the learning process undertaken by MGMP revitalization program participants. There are variables that are bridged so that knowledge and skills bring the desired impact of MGMP revitalization program implementation, motivating each participant to apply the knowledge and skills gained in the context of performance. Overall the implementation of the MGMP revitalization program has been able to improve the knowledge and skills of discourse on the philosophical and theoretical foundations of learning English. The obstacle that arises is the lack of motivation from many participants to apply knowledge and skills in the context of performance.

Lack of motivation to apply knowledge and skills has resulted in teaching practices that have not changed much. This shows that the forum has not been able to effectively and optimally function and role as media development and professional development of their teachers. These constraints must look for root causes and then comprehensive solutions must be provided, so that effective implementation of the program can be maximized.

\subsection{Discussion}

As explained above, this evaluation study is to determine the effectiveness of MGMP activities in Pidie district to improve the skills and quality control tools of English teachers as classroom practice. In accordance with the characteristics of the activity, the evaluation research is to apply the evaluation model in four steps of Kirkpatrick (the four-level evaluation model of Kirkpatrick's). Variables are the subject of this study including the teacher's reaction in the implementation of MGMP activities, teacher's knowledge and skills after the following MGMP activities, teacher's motivation to transfer knowledge and skills, and the impact of increasing teacher MGMP on teachers. For this reason, Pearl Development and the reliability of the instruments developed in evaluative research are based on training programs from the assessment model developed by Kirkpatrick (1996: 21), and based on the process of interviewing and observing the performance of several participants or the MGMP English Language revitalization program in Pidie District.

Three variables; i.e. reactions, knowledge and skills, motivation and are developed using a Likert scale with 1 range of values (most negative) to 5 (highest score). Although the impacts are only twice (distance scale 2 only); where scale 2 means that the revitalization program has a lot of effects on professional development of teacher performance and scale 1 means that the revitalization program has a small impact on teacher professional development. The reaction of participants or participating in the MGMP revitalization program implementation measured by a ten-point declaration is to determine the level of participant satisfaction with the MGMP program implementation. Positive reaction to program participants, it is hoped that the higher level of knowledge and competence possessed by participants after participating in the revitalization MGMP program. Conversely, the negative reaction from MGMP revitalization program participants, the higher the level of knowledge and competence possessed by participants after 
participating in the revitalization MGMP program. Thus, these items are very reliable to measure the motivation of participants or participants to apply the knowledge and

skills gained after participating in the MGMP revitalization program. Impact. The impact is defined as the end result that occurs as a result of participation in the MGMP revitalization program. The final results include increasing knowledge and skills from the MGMP revitalization program, so that the quality of the learning process in the classroom is better. The better the learning quality of MGMP teacher participants in the revitalization program in class can be used as an indicator that there is an increase in teacher professionalism.

\section{Conclusion}

Research on the implementation of the MGMP English Language revitalization program using evaluative methods shows that the positive reaction of each participant to the implementation of the program has influenced the level of mastery of the knowledge and skills possessed by each participant. However, the acquisition of knowledge and skills does not always have a significant impact on the quality of the learning process undertaken by MGMP revitalization program participants. There are variables that bridge the knowledge and skills that bring the desired impact of the implementation of the program, the motivation of each participant to apply the knowledge and skills gained in the context of performance. Overall the implementation of the MGMP revitalization program has been able to improve the knowledge and skills of discourse on the philosophical and theoretical foundations of learning English. The obstacle that arises is the lack of motivation from many participants to apply knowledge and skills in the context of performance. Lack of motivation to apply knowledge and skills has resulted in teaching practices that have not changed much. This shows that the forum has not been able to effectively and optimally function and role as media development and professional development of their teachers. This obstacle must find the root cause and then a comprehensive solution must be provided, so that the effectiveness of program implementation can be maximized.

\section{Acknowledgements}

This research was supported by The Ministry of Research, Technology and Higher Education of the Republic of Indonesia (KEMENRISTEKDIKTI) [Grant Number: 004/SPK/LPPM.UNIGHA/IV/2019]

\section{References}

Arikunto, Suharsimin. (2007). Manajemen Pendidikan. Jakarta:PT Rineka Cipta

Arni Hayati, dkk. (2009). Guru Bermutu Pendidikan Juga Bermutu. www.Fai.Uhamka.ac.id

Celce-Murcia, M., Dornyei, Z., \& Thurrell, S. (1995). Communicative Competence: A Pedagogically Motivated Model with Content Specifications. Issues in Applied Linguistics 6; 2; pp. 5-35

Depdiknas. (2005). Undang-undang nomor 14, tahun 2005, tentang Guru dan Dosen. Fasli Jalal. (2005) Teachers' Quality Improvement in Indonesia: New Paradigm and Milestones. Jakarta: Departemen Pendidikan Nasional. 
Saondi, Ondi dan Suherman, Aris. (2010). Etika Profesi Keguruan, PT Refika Aditama: Bandung.

Sugiyono. (2007). Metode Penelitian Pendidikan: Pendekatan Kuantitatif, Kualitatif, dan R \& D. Bandung: Alfabeta.

Soetjipto, \& Raflis, K. (2009). Profesi Keguruan. Jakarta: Rineka Cipta.

Uno, Hamzah B. (2007). Model Pembelajaran Menciptakan Proses Belajar Mengajar yang

Kreatif dan Efektif. Jakarta: Bumi Aksara

Undang-undang Republik Indonesia Nomor 20 tahun 2003. Tentang Sistem pendidikan nasional. Peraturan Pesiden Nomor 87 Tahun 2017 tentang penguatan pendidikan karakter.

Zulkifli and Ridwan, Muhammad. 2019. Revitalization of the traditional values lost due to the commodification of art/crafts: a case study of Bataknese traditional Ulos. Asian Ethnicity, 541-554.

Website:

http://www.definisi-pengertian.com/2015/05/definisi-pengertian-kompetensi-pendidikanguru.html accessed on 15/08/2019 